\title{
Comparative Productivity of Intensively Managed Star and GuineaGrass Pastures in Terms of Milk Production in the Humid Mountain Region of Puerto Rico ${ }^{1,2}$
}

\author{
Rubén Caro Costas and José Vicente Chandler ${ }^{3}$
}

\begin{abstract}
Intensively managed, steep pastures of stargrass outyielded those of guineagrass in terms of milk production when grazed by cows receiving no concentrate feed over a 2-yr period under conditions typical of the humid mountain region of Puerto Rico. Cows on stargrass pastures produced an average of 7,727 liters of milk/ha/yr and provided 729 cow-days of grazing/ $\mathrm{ha} / \mathrm{yr}$, whereas cows on guineagrass pastures produced 5,593 liters/ha/yr and provided 543 cow-days of grazing. Daily milk production per cow was similar for cows fed on either grass. Cows on stargrass pastures produced more milk during all seasons of the year than those on guineagrass pastures. In addition, guineagrass pastures exhibited more seasonal variations in productivity.
\end{abstract}

\section{INTRODUCTION}

Information is abundant on the best management and fertilizer practices to use with tropical grass pastures in the humid mountain region of Puerto Rico. Caro and Vicente-Chandler $(3,4)$ found that when fertilization of napiergrass pastures was increased from 675 to $2,025 \mathrm{~kg}$ of 14-410/ha/yr, weight gains increased from 638 to $1,201 \mathrm{~kg} / \mathrm{ha} / \mathrm{yr}$, carrying capacity from 3.5 to 5.5273 -kg steers/ha, total digestible nutrients from 4,820 to $7,500 \mathrm{~kg} / \mathrm{ha} / \mathrm{yr}$ and protein content of the forage consumed by the grazing cattle from 8.1 to $15.9 \%$. Caro, Vicente-Chandler and Abruña (5) found that pangolagrass pastures responded to fertilization with 15-510 up to $2,688 \mathrm{hg} / \mathrm{ha} / \mathrm{yr}$, producing weight gains of $976 \mathrm{~kg} / \mathrm{ha} / \mathrm{hr}$ with a carrying capacity of five 273-kg steers/ha. Caro, Abruña and VicenteChandler (2) found that stargrass pastures responded strongly to fertilization up to $3,136 \mathrm{~kg}$ of $15-5-10 / \mathrm{ha} / \mathrm{yr}$ both in beef gains and carrying capacity. From these studies it was concluded that the optimum fertilizer rate for those pastures under conditions typical of the humid mountain region of Puerto Rico was about $2,200 \mathrm{~kg}$ of $15-5-10 / \mathrm{ha} / \mathrm{yr}$ divided into four equal applications every 3 months.

'Manuscript submitted to Editorial Board October 4, 1978.

${ }^{2}$ This paper covers investigations conducted cooperatively by the Science and Education Administration, USDA and the Agricultural Experiment Station, Mayagüez Campus, University of Puerto Rico, Rio Piedras, P.R.

${ }^{3}$ Agronomist, cooperative between the Science and Education Administration, USDA and the Agriculatural Experiment Station, Mayagüez Campus, University of Puerto Rico, and Location Leader-Soil Scientist, Science and Education Administration, USDA, Río Piedras, P.R., respectively. 
Vicente-Chandler, Caro and Figarella (9) found that well fertilized, intensively managed paragrass and molassesgrass pastures produced an average of only $712 \mathrm{~kg}$ of gain weight/ha/yr, wheras napiergrass, guineagrass and pangolagrass produced similar gain in weight, averaging 1,181 $\mathrm{kg} / \mathrm{ha} / \mathrm{yr}$, and carried $6.1273-\mathrm{kg}$ head/ha. These pastures produced an average of $8,466 \mathrm{~kg}$ of total digestible nutrients/ha/yr and the cattle consumed approximately $15,700 \mathrm{~kg}$ of dry forage/ha/yr with a crude protein content averaging 18\%. Caro, Abruña and Vicente-Chandler (1) found that stargrass receiving $2,240 \mathrm{~kg} / \mathrm{ha} / \mathrm{yr}$ of $15-5-10$ produced 1,514 $\mathrm{kg}$ of weight gain/ha/yr and carried $7.4273-\mathrm{kg}$ animals/ha whereas pangolagrass pastures produced $1,062 \mathrm{~kg}$ of gain in weight/ha/yr and carried $6.5 \mathrm{head} / \mathrm{ha}$. Crude protein content of the stargrass consumed by the grazing cattle ranged from 15 to $25 \%$ throughout the year, and digestibility was about $55 \%$.

Caro and Vicente-Chandler (6) found that nine Holstein cows fed exclusively on well fertilized, intensively managed grass pastures on steep slopes and receiving no concentrate feed, produced an average of 2,044, $3,696,3,897,4,058$ and 4,817 liters of milk per lactation during five consecutive lactations. These figures show that cows on pastures can produce high yields of milk with no concentrate feed.

Although data is abundant on the productivity of intensively managed tropical grass pastures in terms of beef production and carrying capacity, there is little information on their productivity in terms of milk production.

This paper presents the results of a 2-year experiment during which cows fed exclusively on pastures were used to determine the comparative milk production of cows on steep, well fertilized, intensively managed stargrass and guineagrass pastures under conditions typical of the humid mountain region of Puerto Rico.

\section{MATERIALS AND METHODS}

The experiment was carried out in cooperation with a commercial dairy where all cows were fed exclusively on intensively managed tropical grass pastures and received no concentrate feed.

The experimental area is at an elevation of about $600 \mathrm{~m}$. The mean average annual temperature is about $24^{\circ} \mathrm{C}$, maximum daily temperature rarely exceeds $31^{\circ} \mathrm{C}$ and the minimum is seldom less than $18^{\circ} \mathrm{C}$. Annual rainfall averages about $160 \mathrm{~cm}$ and is fairly well distributed throughout the year.

The herd consisted of Holstein cows of different ages and origins. It included first calf heifers from Wisconsin, first calf heifers from an adjacent farm in Puerto Rico that had been raised on all-grass rations, and older cows. All cows were milked twice daily in a modern milking parlor. 
Five pastures of stargrass totalling 24.4 ha, and 5 pastures of guineagrass totalling $25.2 \mathrm{ha}$, were used in a randomized design. The soil was a deep, red, acid Humatas clay with excellent physical conditions. The average slope was $35 \%$. The soil was limed to about pH 5.5 and fertilized with $2,240 \mathrm{~kg}$ of $15-5-10 / \mathrm{ha} / \mathrm{yr}$ in four equal applications. Fresh water, mineralized salt and bone meal were available in all pastures. The cows were kept on the pastures at all times except during milking.

The milking herd ranged from 140 to 150 cows. Each pasture was grazed for 1 to 2 days and then rested for about 3 weeks before being grazed again.

Records were kept of the milk the cows produced when grazing each pasture and of the cow-days of grazing provided by each enclosure over the 2-yr period.

TABLE 1.-Monthly rainfall in the experimental area during the 2 years of experimentation

\begin{tabular}{lrrr}
\hline \multicolumn{1}{c}{ Month } & 1974 & 1975 & Average \\
\hline & $m m$ & $m m$ & $m m$ \\
January & 154 & 178 & 165 \\
February & 73 & 5 & 39 \\
March & 75 & 126 & 101 \\
April & 126 & 142 & 134 \\
May & 152 & 78 & 115 \\
June & 29 & 19 & 24 \\
July & 73 & 130 & 102 \\
August & 125 & 118 & 122 \\
September & 182 & 392 & 287 \\
October & 618 & 97 & 357 \\
November & 297 & 376 & 236 \\
December & 151 & 268 & 219 \\
\hline \multicolumn{1}{c}{ Total } & 2055 & 1727 & 1893 \\
\hline
\end{tabular}

\section{RESULTS AND DISCUSSIONS}

Table 1 shows monthly and total rainfall during the 2-yr. experiment. Rainfall totalled 2,056 $\mathrm{mm}$ in 1974 and $1,727 \mathrm{~mm}$ in 1975. Monthly extremes ranged from $5.1 \mathrm{~mm}$ in February 1975 to $618 \mathrm{~mm}$ in October 1974 .

Table 2 shows that cows on the stargrass pastures outyielded those on guineagrass, producing an average of 7,727 liters of milk/ha/yr as compared with 5,593 liters/ha/yr on guineagrass. Cow-days of grazing averaged $729 / \mathrm{ha} / \mathrm{yr}$ for stargrass as compared with only 543 for guineagrass. Daily milk production per cow, however, averaged only slightly more for stargrass than for guineagrass: 10.6 and 10.2 liters/cow/day, respectively. It is therefore evident that the higher milk yields produced by the 
stargrass pastures resulted from higher forage yields, as reflected in more cow-days on grazing, rather than from better quality forage, which would probably have been reflected in higher daily milk production per cow. This agrees with the findings of Vicente-Chandler et al. (8), which showed little difference in the nutritive value of most tropical grasses if they are managed similarly.

Table 2 also shows that the stargrass pastures produced more total digestible nutrients $(5,236 \mathrm{~kg} / \mathrm{ha} / \mathrm{yr})$ consumed by the grazing cattle than did guineagrass $(3,872 \mathrm{~kg} / \mathrm{ha} / \mathrm{yr})$. These levels of total digestible nutrients are rather low compared with those found by Caro et al. $(1,2)$ for young

TABLE 2.-Productivity over a 2-yr period of intensively managed stargrass and guineagrass pastures grazed by cows receiving no concentrate feed

\begin{tabular}{|c|c|c|c|c|c|}
\hline Pasture & Area (ha) & $\begin{array}{l}\text { Milk produc- } \\
\text { tion }\end{array}$ & Grazing provided & $\begin{array}{l}\text { Average daily milk } \\
\text { production per cow }\end{array}$ & $\begin{array}{l}\text { Total digestible nutri- } \\
\text { ents in forage con- } \\
\text { sumed }\end{array}$ \\
\hline \multirow{2}{*}{\multicolumn{6}{|c|}{$\begin{array}{r}\text { Cow-days/ha/yr } \\
\text { Stargrass }\end{array}$}} \\
\hline & & & & & \\
\hline S-1 & 5.6 & 7,567 & 734 & 10.3 & 5,206 \\
\hline S-2 & 4.0 & 9,573 & 923 & 10.4 & 6,564 \\
\hline S-3 & 4.8 & 11,260 & 1,008 & 11.1 & 7,410 \\
\hline S-4 & 8.0 & 4,876 & 467 & 10.5 & 3,331 \\
\hline S-5 & 2.0 & 7,422 & 710 & 10.4 & 5,067 \\
\hline \multicolumn{2}{|c|}{ Weighted average } & $7,727^{2}$ & $729^{2}$ & 10.6 & $5,236^{2}$ \\
\hline \multicolumn{6}{|c|}{ Guineagrass } \\
\hline G-1 & 3.2 & 6,780 & 664 & 10.1 & 4,690 \\
\hline G-2 & 3.2 & 6,323 & 625 & 10.1 & 4,397 \\
\hline $\mathrm{G}-3$ & 4.8 & 3,980 & 388 & 10.3 & 2,746 \\
\hline $\mathrm{G}-4$ & 6.0 & 5,725 & 553 & 10.4 & 3,930 \\
\hline G-5 & 8.0 & 5,696 & 549 & 10.3 & 3,905 \\
\hline \multicolumn{2}{|c|}{ Weighted average } & 5,593 & 543 & 10.2 & 3,872 \\
\hline
\end{tabular}

${ }^{1}$ Cows weighed an average of $500 \mathrm{~kg}$. They required $4 \mathrm{~kg}$ of total digestible nutrients daily plus $0.3 \mathrm{~kg}$ per liter of milk produced.

${ }^{2}$ Differences are statistically different at the $1 \%$ probability level.

cattle grazing small enclosures. This difference is possibly due to the more efficient use of the forage produced in these authors' grazing experiments, where rather small pastures ( $0.4 \mathrm{ha}$ ) were used, compared to the much larger pastures under commercial farm conditions used in this experiment.

Figure 1 shows that cows on stargrass pastures produced more milk during all seasons of the year than did those on guineagrass and that guineagrass also varied more in production from one season to another than did stargrass.

Cows on stargrass pastures produced an average of 7,727 liters of milk/ 
ha/yr which had a farm value of about $\$ 2,700 /$ ha/yr with inputs for materials $(2,300 \mathrm{kgs}$ of $15-5-10$ fertilizer $+3 \mathrm{MT}$ of lime/ha/yr) of $\$ 410$. Fairly well-managed dairies in Puerto Rico use $600 \mathrm{~kg}$ of fertilizer/ha/yr, which costs $\$ 1.15$. To produce the same amount of milk as the cows on stargrass pastures did, they feed $3,510 \mathrm{~kg}$ of concentrates costing $\$ 773 /$ ha/yr for a total cost of $\$ 888$ in materials. Thus, by producing milk with

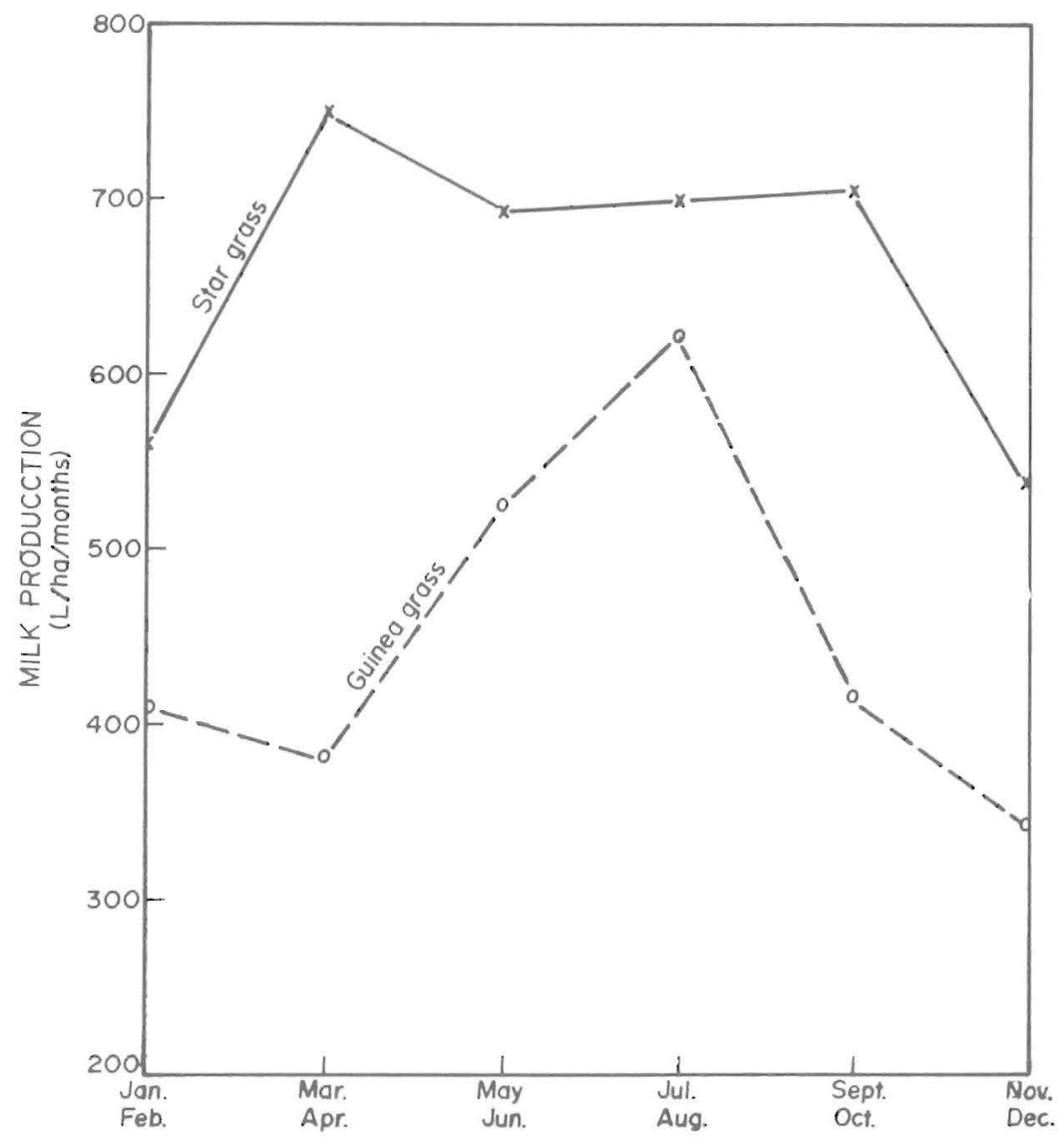

FIG. 1.-A two-year record of average monthly milk production of cows grazing steep intensively managed star and guinea grass pastures without receiving concentrate feed.

cows fed on intensively managed pastures, which are largely the product of the Island's natural resources of climate, soil and water and not feeding concentrates the cost of imported materials could be reduced by more than half from 11.5 to $4.94 \propto$ per liter of milk.

There are about 150,000 ha of deep, moderately steep soils suited to intensively managed grass pastures for milk production in the humid 
mountain region of Puerto Rico. These lands have few alternative uses; they are not suited to mechanized crop production; and they require the protection against erosion that well managed pastures provide.

Serra, Vicente-Chandler and Llorens (7) have shown that net farm income can be increased just as much by using higher producing cows and feeding more concentrates as by acquiring more cows of similar production and putting more land into pastures. The second alternative is more desirable for the Island's economy. Imports can be reduced sharply and good use made of thousands of hectares in the humid mountain region with a good potential for milk production and few alternative uses.

\section{RESUMEN}

Durante 2 años se determinó la productividad bajo condiciones típicas de la región montañosa de Puerto Rico de los pastos estrella y guinea cultivados intensivamente y pastados por vacas lecheras que no recibían alimento concentrado alguno.

Con el pasto estrella fue posible producir un promedio de 7,727 litros de leche/ha y año con 729 días-vaca de pastoreo/ha y año comparado con un promedio de 5,593 litros de leche/ha y año y 543 días-vaca de pastoreo con el guinea. La producción de leche/vaca y día fue similar en ambos casos. Con el pasto estrella se produjo más leche durante todas las épocas del año que con el guinea, con el cual la producción, además, varió más según la época del año.

Las vacas en los pastos estrella produjeron leche con un valor de alrededor de $\$ 2,700 /$ ha y año con insumos importados ascendentes a sólo 4.94 centavos/litro de leche. En Puerto Rico, en vaquerías bien administradas el costo de los insumos importados ascienden a alrededor de 11.5 centavos/litro de leche. Produciendo la leche mayormente en pastos, se puede hacer un mejor uso de los recursos de clima, suelo y agua de la región montañosa húmeda, donde hay más de 150,000 hectáreas aptas para la producción de pastos para ganado lechero y que ofrecen pocos usos alternos.

\section{LITERATURE CITED}

1. Caro-Costas, R., Abruña, F., and Vicente-Chandler, J., 1972. Comparison of heavily fertilized Pangola and Stargrass pastures in terms of beef production and carrying capacity in the humid mountain region of Puerto Rico, J. Agri. Univ. P.R. 56(2): 10410.

2. - Abruña, F., and Vincente-Chandler, J., 1976. Effect of three levels of fertilization on the productivity of Stargrass pastures growing on a steep Ultisol in the humid mountain region of Puerto Rico, J. Agri. Univ. P.R. 60(2): 172-178.

3. - , and Vincente-Chandler, J., 1961. Effect of fertilization on carrying capacity and beef produced by Napiergrass pastures, Agron. J. 53(3): 204-5.

4. - , and Vincente-Chandler, J., 1972. Effect of heavy rates of fertilization on beef 
production and carrying capacity of Napiergrass pastures over 5 consecutive years of grazing under humid tropical conditons, J. Agri. Univ. P.R. 56(3): 223-27.

5. - Vicente-Chandler, J., and Abruña, F., 1972. Effect of four levels of fertilization on beef production and carrying capacity of Pangolagrass pastures in the humid mountain region of Puerto Rico, J. Agri. Univ. P.R. 56(3): 219-22.

6. - and Vicente-Chandler, J., 1974. Milk production by Holstein cows fed only on grass during five consecutive lactations, J. Agri. Univ. P.R. 58(1): 18-25.

7. Serra, G., Vicente-Chandler, J., and Llorens, A., 1974. Aspectos económicos de la ganadería en pastos intensivamente cultivados en la altura húmeda de Puerto Rico, Esta. Exp. Agri., Univ. P.R., Publ. 83.

8. Vicente-Chandler, J., Abruña, F., Caro-Costas, R., Figarella, J., Silva, S., and Pearson, W., 1974. Intensive grassland management in the humid tropics of Puerto Rico, Agri. Exp. Stn., Univ. P.R., Bull. 233.

9. - Caro-Costas, R., and Figarella, J., 1965. Productivity of intensively managed pastures of five grasses on steep slopes in the humid mountains of Puerto Rico, J. Agri. Univ. P.R., 49(1): 99-111. 